\title{
Utilization of Biochar and Mycorrhiza to Increase the Absorption of Elemental Nutrients of Cayenne Chili (Capsicum frutescens L.)
}

\author{
Bibiana Rini Widiati Giono ${ }^{1 *}$, Muchtar Salam Solle ${ }^{2}, \operatorname{Sofyan}^{1}$ and Muhammad Izzdin Idrus ${ }^{1}$ \\ ${ }^{l}$ Agrotechnology Study Program, Faculty of Agriculture, Animal Husbandry and Forestry, Muslim University of \\ Maros, Maros, South Sulawesi 90512, Indonesia \\ ${ }^{2}$ Department of Soil Science, Faculty of Agriculture, Hasanuddin University, Makassar, \\ South Sulawesi 90245, Indonesia \\ *Corresponding author e-mail: widiatirini@gmail.com
}

Received February 23, 2021; Revised March 12, 2021; Accepted 20 May 2021

\begin{abstract}
This study aimed to study the relationship between biochar as a soil enhancer and mycorrhizal dose on the nutrient uptake of cayenne plants. The experiment was done in a split-plot design with a randomized block design. The main plot was a vesicular-arbuscular mycorrhiza or VAM $(\mathrm{m})$ with three levels: $10 \mathrm{~g} \mathrm{plant}^{-1}$ mycorrhiza $\left(\mathrm{m}_{1}\right), 15 \mathrm{~g} \mathrm{plant}^{-1}$ mycorrhiza $\left(\mathrm{m}_{2}\right)$, and $20 \mathrm{~g} \mathrm{plant}^{-1}$ mycorrhiza $\left(\mathrm{m}_{3}\right)$. The subplot was a biochar composition as soil enhancer $(\mathrm{b})$ with three levels: $50 \%$ rice husk biochar $+25 \%$ soil $+25 \%$ sand $\left(b_{1}\right), 25 \%$ wood biochar $+25 \%$ soil $+50 \%$ sand $\left(b_{2}\right)$, and $50 \%$ wood biochar $+25 \%$ soil $+25 \%$ rice husk biochar $\left(\mathrm{b}_{3}\right)$. Each level of the VAM dose factor was combined with each level of the biochar composition; each combination was repeated three times, accounting for 27 experimental units. The phosphorus uptake, potassium uptake, and fresh root weight positively correlated to the percentage of mycorrhizal infections. The combination treatment of $20 \mathrm{~g} \mathrm{plant}^{-1}$ mycorrhiza and $50 \%$ rice husk biochar $+25 \%$ soil $+25 \%$ sand; 15 g plant $^{-1}$ mycorrhiza with $50 \%$ wood biochar $+25 \%$ soil $+25 \%$ rice husk biochar; and $20 \mathrm{~g} \mathrm{plant}^{-1}$ mycorrhiza are the best planting medium.
\end{abstract}

Keywords: Mycorrhiza, nutrient, planting media, soil enhancers

\section{INTRODUCTION}

The Capsicum frutescens L (cayenne) plant has a high economic value due to extensive utilization in the food industry or consumption in small households. This high food demand is due to an increased population. When the agricultural sector has not been able to meet all demands, so, in the future, expansion of the area and intensification of agriculture is necessary (Mulyani and Agus 2017). To overcome this problem, utilizing narrow land requires alternative technology, one of which is planting cayenne in a pot to facilitate growth and yield observation.

The composition of the growth media determines plant growth. It should meet the requirements of proper drainage, nutrient retention, and water-resistant to washing by utilizing the availability of local materials (Kazemi and Mohorko 2017). Soil enhancers can be used as an alternative

J Trop Soils, Vol. 26, No. 2, 2021: 75-86

ISSN 0852-257X; E-ISSN 2086-6682 planting medium to improve the soil's physical, biological, and chemical properties. According to Dariah et al. (2015), soil ameliorants can be divided into three categories based on forming compounds, namely organic, biological, and mineral soil ameliorants. Biochar is widely considered organic soil ameliorant as a growth medium. Biochar application to the soil can increase soil carbon content, water retention, and nutrients in the soil, increase the availability of macronutrient cations, increase soil fertility, and improve the quality of degraded soils (Atkinson et al. 2010).

Biochar as a soil enhancer is aimed to increase nutrient availability, cation exchange capacity, nutrient retention, and water (Glaser et al. 2002). Biochar has been potentially used in agriculture, energy sector, environmental purpose, replacement of aggregates in the growing media industry (Ioannidou and Zabaniotou 2007; Nemati et al. 2015). Biochar types are mainly wood-based materials, stone, manure, and leaves (Chrysargyris et al. 2020; Dorais et al. 2016). The temperature 
during the process of biochar pyrolysis significantly influences the increase in carbon content $(773 \mathrm{~K})$, cation exchange capacity, and $\mathrm{pH}$ of the produced biochar (van Zwieten et al. 2010; Surdianto et al. 2015). In addition, biochar has many pores, which results in increased water retention and nutrient availability and decreased nutrient leaching rate (11\% reduction), and soil erosion (Oguntunde et al. 2008; Nemati et al. 2015). A previous study was investigated the potential use of biochar as effective solid media material in the hydroponic system (Karakas et al. 2017; Chrysargyris et al. 2020; Dorais et al. 2016).

Biochar provides a suitable habitat for various soil microbes (Rondon et al. 2007). The shape of the biochar structure, such as pore volume and the surface area, protect beneficial soil microorganisms such as mycorrhiza and bacteria (Atkinson et al. 2010). Inoculation with Vesicular-Arbuscular Mycorrhiza (VAM) can increase various nutrient uptake, nitrogen fixation ability, and growth of green beans (Xiao et al. 2010), as well as significantly increase the absorption of phosphorus $(\mathrm{P})$, sulfur $(\mathrm{S})$, magnesium $(\mathrm{Mg})$, and zinc $(\mathrm{Zn})$ and soybean crop yields (Karaca et al. 2013).

According to Adelman and Morton (1986), a mycorrhizal infection can enhance plant growth and its ability to utilize nutrients present in the soil, especially the $\mathrm{P}, \mathrm{Ca}, \mathrm{N}, \mathrm{Cu}, \mathrm{Mn}, \mathrm{K}$, and $\mathrm{Mg}$ elements. VAM is associated with most terrestrial plants, providing nutrition and protection from environmental stresses (Aggarwal et al. 2011). Mycorrhizal fungi increase nutrient uptake of $\mathrm{P}$ and $\mathrm{Zn}$ in plant tissue (Lehmann et al. 2014), increase nutrient uptake of $\mathrm{N}, \mathrm{P}, \mathrm{K}$ in chili plants (Carballar-Hernández et al. 2018). VAM inoculation can increase rhizosphere soil aggregates and host plant growth compared with controls (Zhang et al. 2019). The use of biofertilizers requires an appropriate dose of fertilizer application so that the results obtained can meet expectations (Simanjuntak et al. 2017). Mycorrhiza requires suitable biochar composition as a soil enhancer to increase the density of its spore population at the correct dose.

The purpose of the research was to study the effect of biochar composition as a growth medium and mycorrhizal dose on the nutrient uptake of cayenne plants.

\section{MATERIALS AND METHODS}

\section{Experimental Design}

The laboratory experiment was conducted in Damai Village, Maros District, South Sulawesi, in
February-July 2018. This study used a split-plot design with a randomized block design. The main plot was VAM (m) with three levels: $10 \mathrm{~g}^{\text {plant }}{ }^{-1}$ mycorrhiza $\left(\mathrm{m}_{1}\right), 15 \mathrm{~g}$ plant $^{-1}$ mycorrhiza $\left(\mathrm{m}_{2}\right)$, and $20 \mathrm{~g} \mathrm{plant}^{-1}$ mycorrhiza $\left(\mathrm{m}_{3}\right)$. The subplot is biochar composition as soil enhancer (b) with three levels: $50 \%$ rice husk biochar $+25 \%$ soil $+25 \%$ sand $\left(b_{1}\right)$, $25 \%$ wood biochar $+25 \%$ soil $+50 \%$ sand $\left(b_{2}\right)$, and $50 \%$ wood biochar $+25 \%$ soil $+25 \%$ rice husk biochar $\left(b_{3}\right)$. Each VAM dose and biochar factor level was combined, so there are nine combinations of treatment. Each level combination treatment was repeated three times, accounting for 27 experimental units (Figure 1).

Vesicular-arbuscular mycorrhiza (Super Mycorrhiza produced by CV. Abadi Sejahtera, Indonesia) is a type of Glomus sp. and Gigaspora sp (3460 spores per $100 \mathrm{~g}$ zeolite). All treatments were done using podzolic soil, zeolite soil as a carrier, and a manually watering system. Nitrogen, phosphorus, and potassium (NPK) fertilizer (16:16:16) in a concentration equal to $320 \mathrm{mg} \mathrm{N} \mathrm{kg}$ soil $^{-1}$ was added to the soil at two weeks after planting, early flowering phase, and two weeks after flowering (Horel et al. 2019).

\section{Biochar Treatment}

\section{Chaff Charcoal}

Fire-resistant zinc/aluminum cylinder-sized 20 liters were needed. First, the top of the cylinder was discarded. Then, in the bottom, a circular hole was made of $10 \mathrm{~cm}$ in diameter. Then holes were made with nails on the cylinder wall (diameter approximately $0.5 \mathrm{~cm}$ ) with a distance between holes about $2-3 \mathrm{~cm}$. After that, a $1 \mathrm{~cm}$ long zinc pipe with a $10 \mathrm{~cm}$ diameter was glued, which functions as a chimney placed perpendicular to the middle of the circle. Finally, the bottom part of the cylinder was covered with a dial plate zinc before burning. Fires were made using firewood and cylinder-sized dry leaves that had been made before.

Then cover the fire with a cylinder that has been given the chimney earlier. Next, fill a cylindrical combustion chamber in which it was already aflame with rice husk. The hoarding was carried up to a 1meter height with the top of a pile of chimneys poking out. After 20-30 minutes, the brown husk down was raised when the top of the rice husk was blackened. After all, the husk turns black, flush with water until it was evenly distributed to stop the burning process. After watering, and the temperature decreases, the husk charcoal was dried (Surdianto et al. 2015).

Wood charcoal was obtained from the local market and broken into small sizes. Then it was 


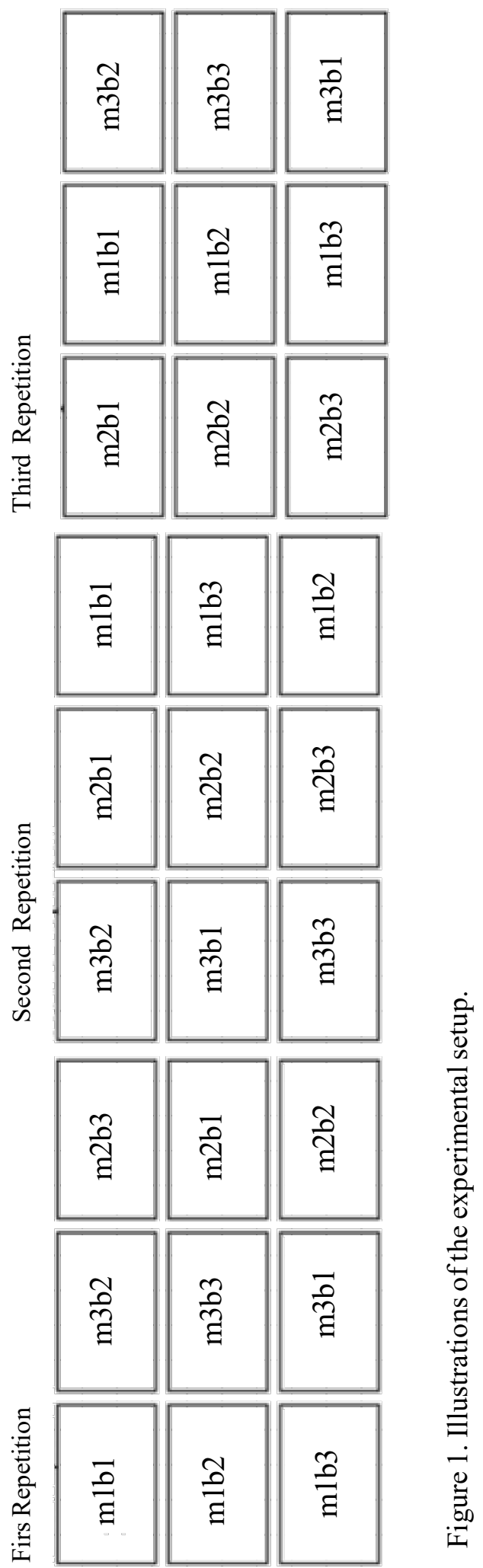

sifted to separate gravel and other impurities. The soil from Abbakae Hamlet, Damai Village, Tanralili District, Maros Regency, South Sulawesi, was airdried for one week and then sifted to separate gravel and other impurities and weighed $1.625 \mathrm{~kg}$ polybag $^{-1}$. Planting media was prepared by mixing husk charcoal, wood charcoal, soil, and sand according to the treatment and put into a $30 \times 40$ $\mathrm{cm}$ polybag with a media weight (soil + biochar) of $6.5 \mathrm{~kg}$ polybag ${ }^{-1}$.

\section{VAM Inoculation}

The material used in this research is VAM (Super Mycorrhiza, CV Abadi Sejahtera, Indonesia), cayenne chili seeds (var. Dewata f1). The seeds were soaked in warm water for 1 hour and spread on the growth media for 12 days before transplantation. The planting hole was of 3 to $5 \mathrm{~cm}$ depth on the planting medium that has been prepared. Mycorrhiza was inoculated when transplanting by giving them directly to the planting hole according to the treatment dose, then the seeds were placed and then covered again with the planting media.

\section{Plant Parameters}

The plant parameters observed included root and shoot dry weight $\left(\mathrm{g} \mathrm{plant}^{-1}\right)$ and $\mathrm{N}, \mathrm{P}$, and $\mathrm{K}$ content of plant tissue (\%). Shoots (taken from the root base to the shoot without chili) and root (taken from the base of the root to the tip of the root) wet weight $\left(g_{\tan ^{-1}}\right)$ were measured at harvest. Dried root weight $(\mathrm{g})$ and dried canopy weight $(\mathrm{g})$ were observed after the roots and canopy of plants were dried in an oven at $600{ }^{\circ} \mathrm{C}$ for $2 \times 24$ hours (Soil Research Center 2009). Plant tissue was analyzed 73 days after planting, which included $\mathrm{N}, \mathrm{P}$, and $\mathrm{K}$ uptake. $\mathrm{N}$ analysis was performed using the Kjeldahl method by the wet ashing with $\mathrm{H}_{2} \mathrm{SO}_{4}$ (Soil Research Center 2009). The $\mathrm{P}$ and $\mathrm{K}$ analyses were extracted by the wet ashing method using $\mathrm{HNO}_{3}$ and $\mathrm{HClO}_{4}$ (Soil Research Institute, 2009). Furthermore, the levels of nutrients were measured by UV-VIS spectrophotometer, flame photometer, and atomic absorption spectrophotometer (Indonesian Soil Research Center 2009).

\section{Calculation of VAM Infection and Its Population in the Medium}

The root infections were analyzed by the staining method, according to Kormanik et al. (1980). First, the roots were soaked in $10 \% \mathrm{KOH}$ solution for 24 hours until the roots appeared white or clear yellow. Then, the roots were rinsed and soaked in $10 \% \mathrm{H}_{2} \mathrm{O}_{2}$ for several minutes, followed by a $2 \%$ $\mathrm{HCl}$ solution for 24 hours. Next, the roots were soaked in a staining solution until the roots turned bluish red for 24 hours. Then, the roots were soaked with $250 \mathrm{ml}$ staining solution for 24 hours, which contained $100 \mathrm{ml}$ glycerin $+100 \mathrm{ml}$ lactic acid +50 $\mathrm{ml}$ distilled water. 
Stained roots were observed by cutting for 1 $\mathrm{cm}$. Then, the roots were arranged on top of the preparation and covered with a glass cover. Ten root pieces of each preparation were observed. The presence of vesicles detected root infections, arbuscules, hyphae, or spores that infect the roots and then documented by Nikon Eclipse $80 \mathrm{i}$ camera microscope $(M=40 \times-1000 \times)$. The calculation of root infection uses the following formula (Equation 1).

$$
\% I R=\left(\frac{I R}{T_{R S}}\right) \times 100 \%
$$

Where \%IR: percentage of an infected root; IR: number of an infected root; $\mathrm{T}_{\mathrm{RS}}$ : total root samples.

Soil spore density was calculated using the wet sieve method (An et al. 1990). Fifty grams of rhizosphere soil samples from each pot were suspended independently in $250 \mathrm{ml}$ of water, and the suspension was stirred and filtered. AM mold spores were collected on a $50 \mathrm{~mm}$ sieve and then transferred to a $9 \mathrm{~cm}$ Petri dish for counting under a microscope dissecting Olympus Sz-51 $(M=0.8-4 \times)$.

\section{Statistical Analysis}

Data were statistically analyzed based on analysis of variance (ANOVA) at a 5\% level. Then, the mean value difference was analyzed using the least significant difference test (LSD).

\section{RESULTS AND DISCUSSION}

\section{Significance of Mycorrhizal and Biochar Application Toward Plant Growth and Development}

Table 1 presents the $\mathrm{F}_{\text {-count }}$ for ANOVA of several observational parameters. It shows whether it is statistically different from the mycorrhizal, biochar, and combination of mycorrhizal and biochar effects toward the canopy and dried fresh root weight parameters, dried canopy and root weight, and N, P, K absorption, mycorrhizal population, and percentage of mycorrhizal infections.

\section{Fresh Canopy and Roots Weight}

\section{Fresh Canopy Weight}

Mycorrhiza, biochar, and combination of mycorrhiza and biochar treatments have a significant effect on fresh canopy weight (Table 1). However, it was not significantly different from mycorrhiza 10 g plant $^{-1}$ and wood charcoal biochar $50 \%+$ soil $25 \%$ +biochar charcoal husk 25\% $\left(\mathrm{m}_{1} \mathrm{~b}_{3}\right)$, mycorrhiza $15 \mathrm{~g} \mathrm{plant}^{-1}$ and wood charcoal biochar $50 \%+$ soil $25 \%+$ biochar charcoal husk $25 \%\left(\mathrm{~m}_{2} \mathrm{~b}_{3}\right)$ to the fresh cayenne canopy weight (Table 2 ). The biochar has a function to retain moisture so that it helps plants in times of lack of water and nutrient retention in the soil so that nutrients present in the soil are avoided from the washing process and will ultimately affect the increase in plant growth (Lehmann et al. 2003). In addition, biochar is good for increasing $\mathrm{C}, \mathrm{N}, \mathrm{P}$, and soil $\mathrm{pH}$ (Chan et al.

Table 1. Effect the mycorrhiza, biochar, and combination of mycorrhiza and biochar treatments on observed parameters.

\begin{tabular}{lccccc}
\hline \multirow{2}{*}{\multicolumn{1}{c}{ Parameter }} & \multicolumn{3}{c}{$\mathrm{F}_{\text {Account }}$} & \multicolumn{2}{c}{ F-Table } \\
\cline { 2 - 5 } & $\begin{array}{c}\text { The main plot } \\
\text { (mycorrhiza) }\end{array}$ & $\begin{array}{c}\text { Subplot } \\
\text { (biochar) }\end{array}$ & $\begin{array}{c}\text { Combination PU x AP } \\
\text { (mycorrhiza x Biochar) }\end{array}$ & 0.05 & 0.01 \\
\hline Fresh canopy weight & $27.554 * *$ & $22.393 * *$ & $18.052 * *$ & $(\mathrm{~m}) 6.944$ & 18.000 \\
Fresh roots weight & $10.235 *$ & $0.449 \mathrm{sn}$ & $0.596 \mathrm{sn}$ & $(\mathrm{b}) 3.885$ & 6.927 \\
Dried canopy weight & $1.846 \mathrm{sn}$ & $0.155 \mathrm{sn}$ & $1.991 \mathrm{sn}$ & $(\mathrm{m} \times \mathrm{b}) 3.259$ & 5.412 \\
Dried roots weight & $0.874 \mathrm{sn}$ & $0.038 \mathrm{sn}$ & $2.800 \mathrm{sn}$ & & \\
Nitrogen uptake & $27.550 * *$ & $1.302 \mathrm{sn}$ & $1.466 \mathrm{sn}$ & \\
Phosphor uptake & $1.658 \mathrm{sn}$ & $2.300 \mathrm{sn}$ & $3.399 *$ & \\
Potassium uptake & $2.146 \mathrm{sn}$ & $6.042 *$ & $3.117 \mathrm{sn}$ & \\
Mycorrhizal population & $11.049 *$ & $34.349 * *$ & $16.183 * *$ & \\
Infection percentage of Mycorrhiza & $213.345 * *$ & $0.964 *$ & $40.504 * *$ & \\
\hline
\end{tabular}

Note: $\mathrm{ns}=$ non-significant; $*=$ significant; $* *=$ highly significant 
Table 2. The mean value of fresh canopy weight ( $\mathrm{g}$ ) on the combination of mycorrhiza and biochar applied to cayenne chili.

\begin{tabular}{|c|c|c|c|c|}
\hline \multirow{2}{*}{ Mycorrhiza } & \multicolumn{3}{|c|}{ Biochar } & \multirow[t]{2}{*}{$\begin{array}{c}\text { NPLSD(b) } \\
1.611 \\
\end{array}$} \\
\hline & b1 & $\mathrm{b} 2$ & b3 & \\
\hline $\mathrm{m} 1$ & $21.138_{y}^{b}$ & $23.958_{x}^{a}$ & $25.402_{x}^{a}$ & \\
\hline $\mathrm{m} 2$ & $19.543_{y}^{b}$ & $24.742_{x}^{a}$ & $25.352_{x}^{a}$ & \\
\hline $\mathrm{m} 3$ & $26.805_{x}^{a}$ & $25.048_{y}^{a}$ & $24.932_{y}^{a}$ & \\
\hline $\mathrm{NPLSD}(\mathrm{m})$ & \multicolumn{4}{|l|}{1.938} \\
\hline \multicolumn{5}{|c|}{$\begin{array}{l}\text { Note:Values followed by the same letters ( } \mathrm{a} \text { and } \mathrm{b} \text { ) in the columns and }(\mathrm{x}, \mathrm{y} \text {, and } \mathrm{z} \text { ) in the same rows } \\
\text { means not significant. LSD } \alpha=0.05 .50 \% \text { husk biochar }+25 \% \text { soil }+25 \% \text { sand }(\mathrm{b} 1), 25 \% \text { wood } \\
\text { biochar }+25 \% \text { soil }+50 \% \text { sand (b2), and } 50 \% \text { wood charcoal biochar }+25 \% \text { soil }+25 \% \text { charcoal } \\
\text { husk biochar (b3), } 10 \mathrm{~g} \mathrm{plant}{ }^{-1} \text { mycorrhiza (m1), } 15 \mathrm{~g} \mathrm{plant}^{-1} \text { mycorrhiza (m2), and } 20 \mathrm{~g} \mathrm{plant} \mathrm{t}^{-1} \\
\text { mycorrhiza (m3). }\end{array}$} \\
\hline
\end{tabular}

2008). Inoculation with mycorrhiza has a more significant effect than biochar, whereas the combination of mycorrhiza and biochar has the most potent effect (Liu et al. 2018).

\section{Fresh Roots Weight}

Table 1 shows that the $\mathrm{F}_{\text {ount }}$ of mycorrhizal treatment has a significant effect, whereas the biochar treatment and the combination of mycorrhiza and biochar have no significant effect on the cayenne, fresh weight. The $20 \mathrm{~g}$ was not significantly different from the $15 \mathrm{~g}$ mycorrhizal dose, but it was significantly different from the $10 \mathrm{~g}$ mycorrhizal dose (Figure 2). According to the study by Echave et al. (2005), mycorrhiza-infected plant roots can increase the fresh weight of canopy and plant roots. Therefore, mycorrhiza plays a vital role in increasing the growth of crops, horticulture, and forest plants (Wubet et al. 2003).

\section{Canopy dan Root Dry Weight}

Mycorrhizal treatment, biochar composition, and the combination did not significantly affect cayenne's canopy and dry root weight (Table 1). Therefore, it is suspected that the role of biochar is not helpful due to the slow decomposition process.

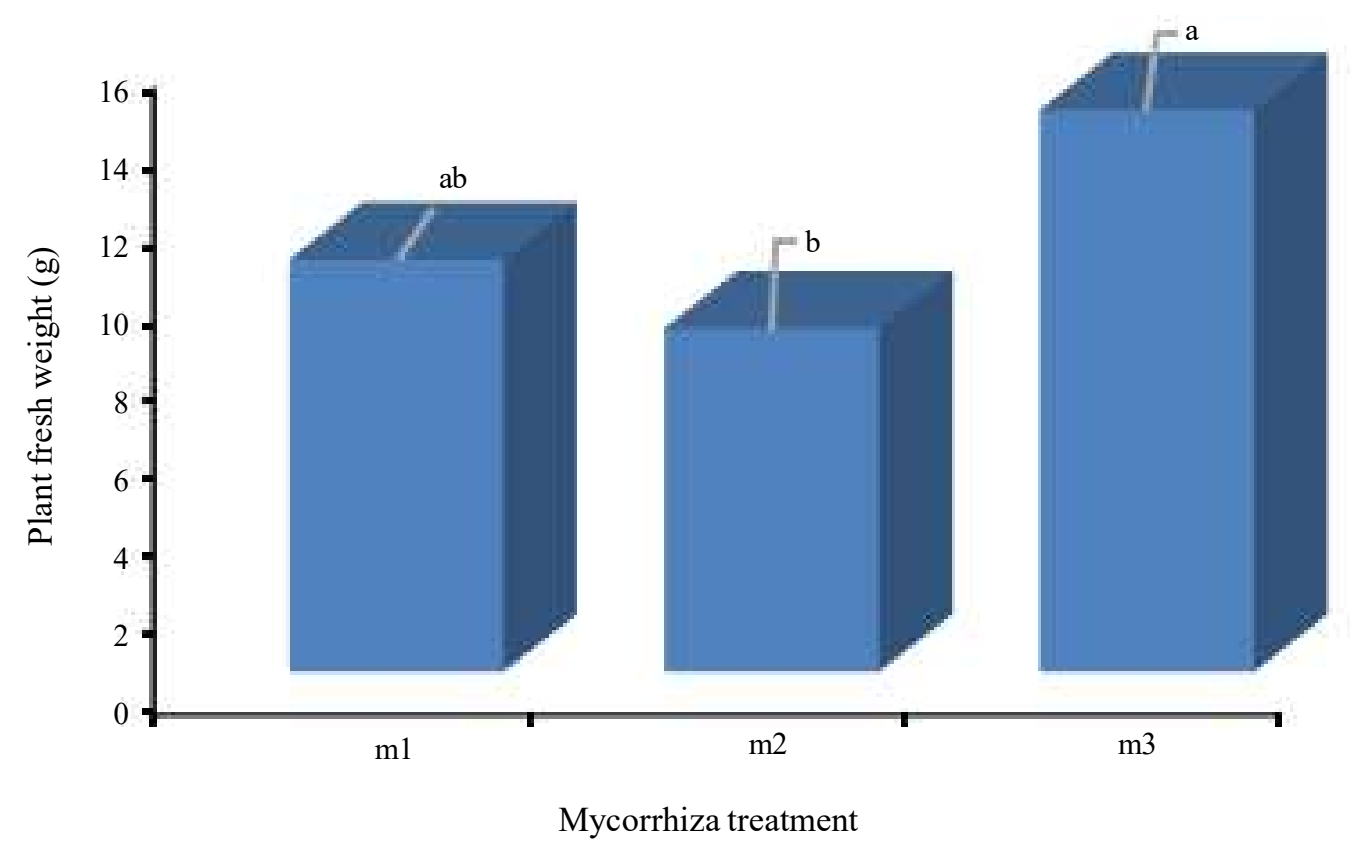

Figure 2. Effect of Mychorriza treatment on plant fresh weight of cayenne plants ( $\mathrm{m} 1$ : $10 \mathrm{~g}_{\text {plant }}{ }^{-1}$ mycorrhiza; m2: $15 \mathrm{~g}_{\text {plant }}{ }^{-1}$ mycorrhiza; and m3: $20 \mathrm{~g} \mathrm{plant}^{-1}$ mycorrhiza). 
According to Schnell et al. (2012), there is no difference in the increase of sourgum biomass with biochar treatment due to the slow recovery of nutrients from biochar. Jaya et al. (2018) also reported that the treatment of biochar types and $\mathrm{N}$ doses is not significantly affected by dry crop stover weight because biochar in the soil has not been well decomposed to affect nutrient release on plant growth vegetative phase.

\section{Nitrogen, Phosphorus, Potassium Uptake of Cayenne Plant}

\section{Nitrogen Uptake}

Based on the ANOVA results, mycorrhizal treatment was significantly affected, while the composition of biochar and its combination did not significantly affect the nitrogen uptake of cayenne plants (Table 1). Application $20 \mathrm{~g} \mathrm{plant}^{-1}$ mycorrhiza $\left(\mathrm{m}_{3}\right)$ was not different from $15 \mathrm{~g} \mathrm{plant}^{-1}$ mycorrhiza $\left(\mathrm{m}_{2}\right)$, but it was different from $10 \mathrm{~g} \mathrm{plant}^{-1}$ mycorrhiza $\left(\mathrm{m}_{1}\right)$ to Nitrogen uptake of cayenne plants (Figure 3). Mycorrhizal inoculation increases the concentration of inorganic nutrients $\mathrm{N}, \mathrm{P}$, and $\mathrm{K}$ and membrane stability that affects the growth and production of chili (Selvakumar and Thamizhiniyan 2011). Mycorrhiza increases nutrient uptake, especially P, N, and Zn (Sharma et al. 2014). The combination of biochar and mycorrhiza positively affects AM mushroom abundance and root colonization (Hu et al. 2014).

Amendola et al. (2017) also reported that the application of biochar in soils improves soil characteristics in terms of available water, organic carbon, and nitrogen, and a significant increase in biomass of root hair. Biochar application can increase soil moisture and $\mathrm{pH}$, thereby stimulating $\mathrm{N}$ mineralization and nitrification, which causes plant uptake increases. Biochar increases the inorganic $\mathrm{N}$ required for plant assimilation by increasing retention and reducing the effects of $\mathrm{N}$ leaching (Nguyen et al. 2017). Biochar reduces $\mathrm{N}$ leaching $\left(\mathrm{NH}_{4}^{+}\right)$, increasing nitrogen retention so $\mathrm{N}$ content in the soil will be high (Li et al. 2019).

\section{Phosphorous Uptake}

The combination of $\mathrm{m}_{2} \mathrm{~b}_{3}$ treatment has a $\mathrm{P}$ absorption value of $0.123 \%$ and is not different from the treatment of $\mathrm{m}_{2} \mathrm{~b}_{1}, \mathrm{~m}_{1} \mathrm{~b}_{2}, \mathrm{~m}_{3} \mathrm{~b}_{3}$, but different from $\mathrm{m}_{1} \mathrm{~b}_{1}, \mathrm{~m}_{1} \mathrm{~b}_{3}, \mathrm{~m}_{2} \mathrm{~b}_{2}, \mathrm{~m}_{3} \mathrm{~b}_{1}, \mathrm{~m}_{3} \mathrm{~b}_{2}$ to phosphorus uptake in cayenne plants. The $m_{2} b_{3}$ treatment was the best (Table 3). According to Schnell et al. (2012), also reported that biochar, which is used as soil ameliorant material, provides nutrients for $\mathrm{N}, \mathrm{P}$, and $\mathrm{K}$. The utilization of biochar and mycorrhiza increases the availability of soil $\mathrm{P}$, expanding the area of root uptake to water associated with external hyphae (Mickan $e t$ al. 2016). Mycorrhizal inoculation is effective in increasing plant $P$ uptake (Selvakumar et al. 2018). The application of biochar to the soil can increase soil C-content, water retention, and nutrients in the soil, increase the availability of significant cations and $\mathrm{P}$, increase soil fertility, and restore degraded soil quality (Karer et al. 2013). Biochar increases CEC, retains $\mathrm{N}$ and $\mathrm{P}$ nutrients, and reduces nutrient leaching (Hale et al. 2013).

Mycorrhizal inoculation applied in the field significantly increases yields compared to plants that are not inoculated. Mycorrhizal inoculation also increases $\mathrm{P}, \mathrm{Z}$, and $\mathrm{Cu}$ absorption by plants $\left(\mathrm{Orta}^{\circ}\right.$ 2019). Mycorrhiza invades plant roots to extract carbohydrates; on the other hand, mycorrhiza assists plants in the $\mathrm{P}$ absorption, similar to nodule-forming bacteria that provide nitrogen to legumes (Parnes 2013). Significant increase in $P$ uptake and yield of

Table 3. The mean value of Phosphor uptake (\%) of cayenne chili plants applied by biochar combination $(\alpha=0.05)$.

\begin{tabular}{|c|c|c|c|c|}
\hline \multirow{2}{*}{ Mycorrhiza (m) } & \multicolumn{3}{|c|}{ Biochar (b) } & \multirow{2}{*}{$\begin{array}{c}\text { NPLSD }(b \\
0.007\end{array}$} \\
\hline & $\mathrm{b} 1$ & $\mathrm{~b} 2$ & b3 & \\
\hline $\mathrm{m} 1$ & $0.096_{z}^{b}$ & $0.120_{x}^{a}$ & $0.111_{y}^{b}$ & \\
\hline $\mathrm{m} 2$ & $0.120_{x}^{a}$ & $0.102_{y}^{b}$ & $0.123_{x}^{a}$ & \\
\hline $\mathrm{m} 3$ & $0.102_{y}^{b}$ & $0.111_{x}^{a b}$ & $0.117^{a b}$ & \\
\hline NPLSD (m) & 0.010 & & & \\
\hline
\end{tabular}

Note: Values followed by the same letters ( $a$ and $b$ ) in the columns and (x,y, and $z$ ) in the same rows means not significant. LSD $\alpha=0.05 .50 \%$ husk biochar $+25 \%$ soil $+25 \%$ sand (b1), $25 \%$ wood biochar $+25 \%$ soil $+50 \%$ sand (b2), and 50\% wood charcoal biochar $+25 \%$ soil $+25 \%$ charcoal husk biochar (b3), 10 g plant $^{-1}$ mycorrhiza (m1), 15 g plant $^{-1}$ mycorrhiza (m2), and 20 g plant $^{-1}$ mycorrhiza (m3). 


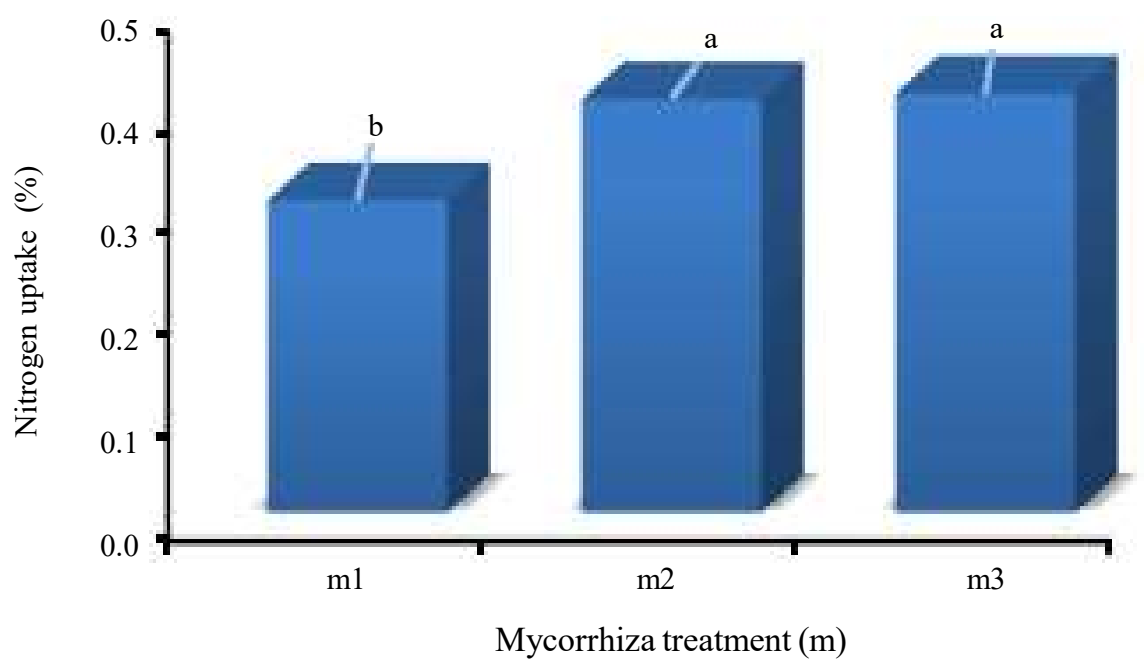

Figure 3. Effect of Mycorrhiza treatment on Nitrogen uptake (\%) of the cayenne plant (m1: $10 \mathrm{~g}$ plant-1 mycorrhiza; $\mathrm{m} 2: 15 \mathrm{~g}_{\text {plant }}{ }^{-1}$ mycorrhiza; and $\mathrm{m} 3: 20 \mathrm{~g} \mathrm{plant}^{-1}$ mycorrhiza).

soybean plants inoculated with G. mosseae (Thioub et al. 2019).

\section{Potassium Uptake}

Based on ANOVA, the biochar treatment was significantly affected, while mycorrhizal treatment and the combination of mycorrhiza and biochar did not significantly affect the Potassium uptake of cayenne plants (Table 1). A $\mathrm{b}_{3}$ treatment is significantly different from $b_{2}$ concerning potassium uptake (Figure 4).

The quality of biochar depends on the manufacturing process and is influenced by temperature, whereas the nutrient content of biochar depends on the raw material of biochar (Gaskin et al.2008). Biochar applications with doses higher than 50 tons $\mathrm{ha}^{-1}$ can improve the soil chemical properties, such as increasing $\mathrm{pH}$, organic carbon, $\mathrm{Na}, \mathrm{K}, \mathrm{Ca}, \mathrm{P}$, cation exchange capacity, but decreasing $\mathrm{Al}$ exchange rate; improve physical soil conditions, such as increased water holding capacity, soil aggregation binding (Chan et al. 2007). Rondon et al. (2007) reported that using biochar for the red bean plant (Phaseolus vulgaris L.) significantly reduced Fe and $\mathrm{Al}$ concentrations and significantly increased $\mathrm{P}, \mathrm{K}$, $\mathrm{Ca}, \mathrm{Mg}$, and $\mathrm{B}$. Also, the concentrations of $\mathrm{S}, \mathrm{Zn}$, $\mathrm{Cu}$, and $\mathrm{Mn}$ did not change. Biochar application significantly increased water retention and nutrients $\mathrm{N}, \mathrm{P}, \mathrm{K}, \mathrm{Mg}, \mathrm{Ca}, \mathrm{Mn}, \mathrm{Cr}, \mathrm{Pb}, \mathrm{B}$, and decreased $\mathrm{Na}$, $\mathrm{Cu}, \mathrm{Ni}$, and $\mathrm{Cd}$ in corn (Glaser et al. 2015).

\section{Mycorrhizal Population and Mycorrhizal Infection Percentage}

\section{Mycorrhizal Population}

The $\mathrm{m}_{3} \mathrm{~b}_{1}$ treatment was not significantly different from $\mathrm{m}_{3} \mathrm{~b}_{3}$, and it was significantly different from the $\mathrm{m}_{3} \mathrm{~b}_{2}, \mathrm{~m}_{2} \mathrm{~b}_{1}$, and $\mathrm{m}_{1} \mathrm{~b}_{1}$ treatments (Table

Table 4. The mean value of mycorrhiza population (per $100 \mathrm{~g}$ growth media) on the application of mycorrhiza and biochar combination to cayenne chili plant.

\begin{tabular}{|c|c|c|c|c|}
\hline \multirow{3}{*}{ Mycorrhiza (m) } & \multirow{2}{*}{\multicolumn{3}{|c|}{$\begin{array}{l}\text { Mean value of mycorrhiza population per } 100 \mathrm{~g} \text { medium } \\
\text { Biochar }(\mathrm{b})\end{array}$}} & \multirow{3}{*}{$\begin{array}{l}\text { NPLSD (b) } \\
\quad 4.378\end{array}$} \\
\hline & & & & \\
\hline & b1 & $\mathrm{b} 2$ & b3 & \\
\hline $\mathrm{m} 1$ & $10_{y}^{c}$ & $\begin{array}{c}7^{b} \\
z\end{array}$ & $17_{x}^{b}$ & \\
\hline $\mathrm{m} 2$ & $17_{x}^{b}$ & $18_{x}^{a}$ & $7_{y}^{c}$ & \\
\hline $\mathrm{m} 3$ & $25_{x}^{a}$ & $18_{y}^{a}$ & $25_{x}^{a}$ & \\
\hline NPLSD (m) & 6.645 & & & \\
\hline
\end{tabular}

Note: Values followed by the same letters ( $a$ and $b$ ) in the columns and (x, y, and $z$ ) in the same rows means not significant. LSD $\alpha=0.05 .50 \%$ husk biochar $+25 \%$ soil $+25 \%$ sand (b1), $25 \%$ wood biochar $+25 \%$ soil $+50 \%$ sand (b2), and 50\% wood charcoal biochar $+25 \%$ soil $+25 \%$ charcoal husk biochar (b3), 10 g plant $^{-1}$ mycorrhiza (m1), 15 g plant $^{-1}$ mycorrhiza (m2), and 20 g plant $^{-1}$ mycorrhiza (m3). 
Table 5. Effect of mycorrhiza and biochar combination on the mycorrhizal infection (\%) of cayenne chili plant.

\begin{tabular}{|c|c|c|c|c|}
\hline \multirow{3}{*}{$\begin{array}{l}\text { Mycorrhiza } \\
\text { (m) }\end{array}$} & \multicolumn{3}{|c|}{ The mean value of mycorrhizal infection (\%) } & \multirow{3}{*}{$\begin{array}{c}\text { NPLSD (b) } \\
5.229\end{array}$} \\
\hline & \multicolumn{3}{|c|}{ Biochar (b) } & \\
\hline & $\mathrm{b} 1$ & $\mathrm{~b} 2$ & b3 & \\
\hline $\mathrm{m} 1$ & $1.67_{y}^{b}$ & $25.00_{x}^{a}$ & $5.00_{y}^{C}$ & \\
\hline $\mathrm{m} 2$ & $5.00_{y}^{b}$ & $3.33_{y}^{b}$ & $13.33_{x}^{b}$ & \\
\hline $\mathrm{m} 3$ & $30.00_{x}^{a}$ & $8.33_{z}^{b}$ & $23.33_{y}^{a}$ & \\
\hline NPLSD (m) & 5.907 & & & \\
\hline
\end{tabular}

Note: values followed by the same letters ( $\mathrm{a}$ and $\mathrm{b}$ ) in the columns and ( $\mathrm{x}, \mathrm{y}, \mathrm{and} \mathrm{z}$ ) in the same rows means not significant. LSD $\alpha=0.05 .50 \%$ husk biochar $+25 \%$ soil $+25 \%$ sand (b1), $25 \%$ wood biochar $+25 \%$ soil $+50 \%$ sand (b2), and 50\% wood charcoal biochar $+25 \%$ soil $+25 \%$ charcoal husk biochar (b3), $10 \mathrm{~g}$ plant $^{-1}$ mycorrhiza (m1), $15 \mathrm{~g}$ plant $^{-1}$ mycorrhiza (m2), and $20 \mathrm{~g} \mathrm{plant}^{-1}$ mycorrhiza (m3).

4). Biochars - complex minerals can increase mycorrhizal colonization, plant growth, and wheat nutrient uptake, especially $\mathrm{N}, \mathrm{P}, \mathrm{K}, \mathrm{S}$, and $\mathrm{Zn}$ (Blackwell et al. 2015). Thus, the addition of biochar has implications for increasing biomass, activity, and composition of soil microorganisms to improve soil quality (Lehmann et al. 2011).

\section{Mycorrhizal Infection}

The treatment of $m_{3} b_{1}$ was not different from $\mathrm{m}_{3} \mathrm{~b}_{2}$, but it was different from the treatment of $\mathrm{m}_{1} \mathrm{~b}_{1}$ and $\mathrm{m}_{1} \mathrm{~b}_{2}, \mathrm{~m}_{1} \mathrm{~b}_{3}, \mathrm{~m}_{2} \mathrm{~b}_{1}, \mathrm{~m}_{2} \mathrm{~b}_{2}, \mathrm{~m}_{2} \mathrm{~b}_{3}, \mathrm{~m}_{3} \mathrm{~b}_{2}$ to the average percentage of mycorrhizal infections in the roots of cayenne plants (Table 5). According to Liu et al. (2018), biochar with AM inoculants significantly increased fungal populations compared to controls. Thus, the application of biochar in water stress environments provides environmental conditions that support mycorrhizal development, increasing mycorrhizal colonization, $\mathrm{P}$ uptake, and water absorption activity concerning extraradical mycelium (Mickan et al. 2016).

Symbiotic associations between fungi and plants (host) form complex interwoven interactions that allow the flow of nutrients, increase the surface area of nutrient uptake of host plants, while the extraradical mycelium (hypha that connects roots to the soil) of the fungus serves as transportation of carbon and other nutrients into the spores (Finlay 2008). Mycorrhizal fungi increase N, P of their host plants while fungi obtain carbon compounds from photosynthesis (Wang et al. 2017). The results of staining the roots of cayenne plants which were then observed with microscope Olympus compound cx-

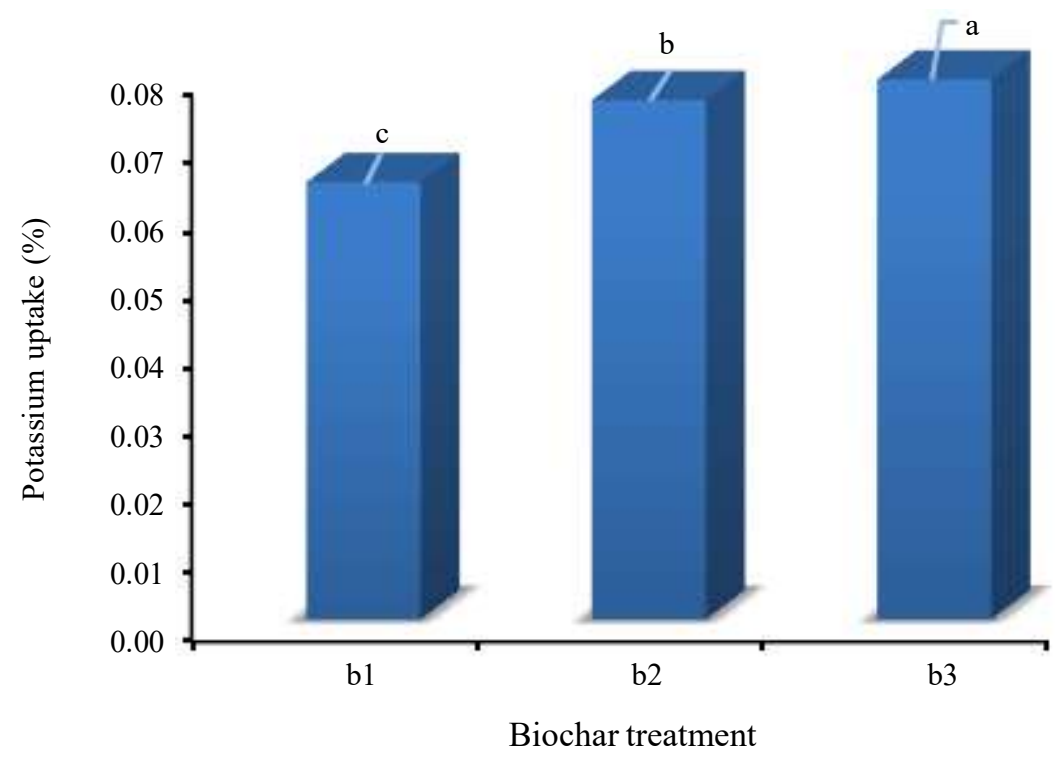

Figure 4. Effect of biochar treatment on the potassium uptake (\%) of the cayenne plant. 
Table 6. A correlation between nitrogen, phosphor, and potassium uptake (\%), fresh canopy weight, fresh roots weight, dried canopy weight, dry roots weight $(\mathrm{g})$, mycorrhiza population (mycorrhiza per $100 \mathrm{~g}$ growth media) (X) and the mycorrhizal infection percentage $(\%)(\mathrm{Y})$.

\begin{tabular}{cllc}
\hline No. & Parameters & Regression formula & $\mathrm{r}$ \\
\hline 1. & Mean of Nitrogen uptake & $\mathrm{y} 1=-0.0001 \mathrm{x}^{2}+0.0043 \mathrm{x}+0,1045$ & $0.375 \mathrm{tn}$ \\
2. & Mean of Phosphor uptake & $\mathrm{y} 2=-3 \mathrm{E}-05 \mathrm{x}^{2}+0.0011 \mathrm{x}+0.032$ & $0.735 *$ \\
3. & Mean of Potassium uptake & $\mathrm{y} 3=-5 \mathrm{E}-05 \mathrm{x}^{2}+0.0015 \mathrm{x}+0.0181$ & $0.876 * *$ \\
4. & Mean of Fresh canopy weight & $\mathrm{y}=-0.0041 \mathrm{x}^{2}+0.2388 \mathrm{x}+22.149$ & $0.528 \mathrm{tn}$ \\
5. & Mean of Fresh roots weight & $\mathrm{y}=-0.0001 \mathrm{x}^{2}+0.0759 \mathrm{x}+2.8083$ & $0.828 * *$ \\
6. & Mean of Dried canopy weight & $\mathrm{y}=0.3791 \ln (\mathrm{x})+5.0222$ & $0.337 \mathrm{tn}$ \\
7. & Mean of Dried roots weight & $\mathrm{y}=0.0401 \ln (\mathrm{x})+0.7656$ & $0.353 \mathrm{tn}$ \\
8. & Mycorrhizal population & $\mathrm{y}=0.0305 \mathrm{x}^{2}-0.7672 \mathrm{x}+17.748$ & $0.404 \mathrm{tn}$ \\
\hline
\end{tabular}
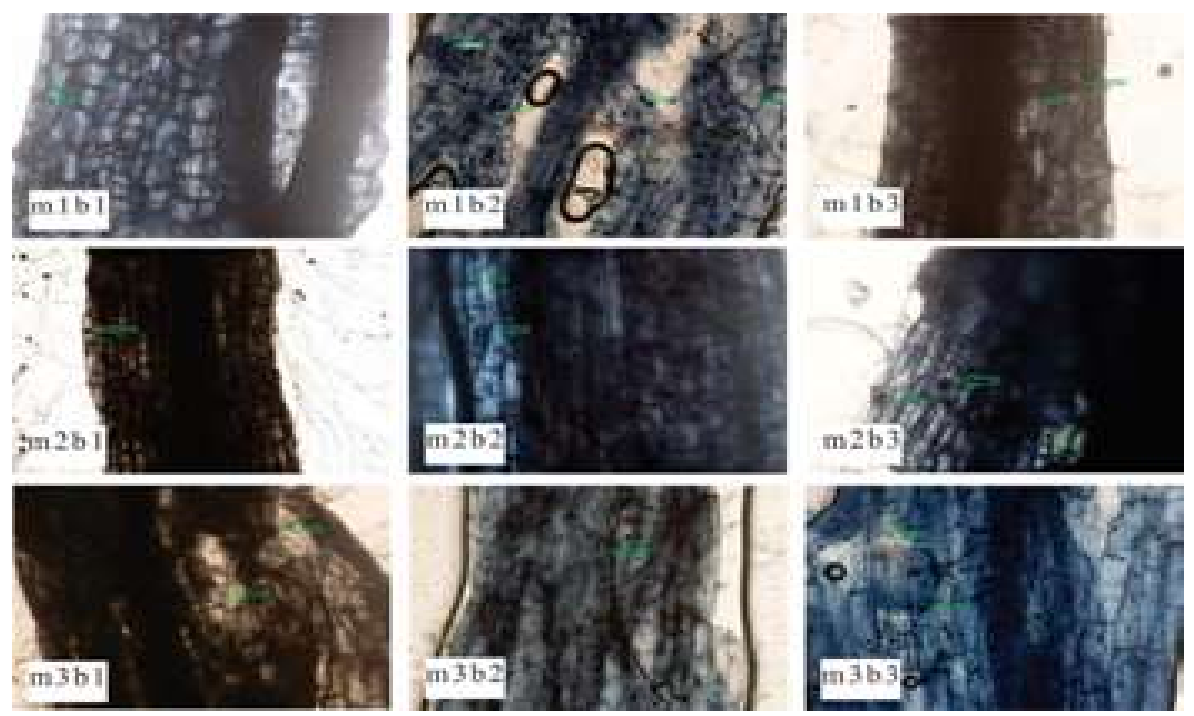

Figure 5. External hyphae $(\mathrm{H})$, vesicular $(\mathrm{V})$, and arbuscules $(\mathrm{A})$ of the treatments $(\mathrm{M}=20 \times) .\left(\mathrm{m} 1: 10 \mathrm{~g}\right.$ plant $^{-1}$ mycorrhiza; $\mathrm{m} 2: 15 \mathrm{~g}$ plant $^{-1}$ mycorrhiza; and $\mathrm{m} 3: 20$ g plant $^{-1}$ mycorrhiza; b1: $50 \%$ husk biochar $+25 \%$ soil $+25 \%$ sand, b2: $25 \%$ wood biochar $+25 \%$ soil $+50 \%$ sand, and b3: $50 \%$ wood charcoal biochar $+25 \%$ soil + $25 \%$ charcoal husk biochar).

31 (magnification: $40 x-1000 x)$ showing the mycorrhizal fungal (CMA) structure in the form of hyphae $(\mathrm{H})$, arbuscular $(\mathrm{A})$, and vesicles $(\mathrm{V})$ in mycorrhizal treatment and biochar Figure 5.

The correlation values of $\mathrm{P}$ uptake, $\mathrm{K}$ uptake, and fresh root weights were $0.735,0.876$, and 0.828 , respectively, indicating a positive and significant relationship between $\mathrm{P}$ and $\mathrm{K}$ uptake with the percentage of mycorrhizal infections (Table 6). The coefficient of determination of phosphorus uptake $r^{2}=0.5404$ (Figure 6). It means that phosphorus absorption in the $54.04 \%$ cayenne plant is determined by the percentage of mycorrhizal infections, whereas other factors determine the remaining $45.96 \%$. Likewise, potassium absorption with a coefficient of determination $\mathrm{r}^{2}=0.7671$ means that the percentage of mycorrhizal infections determines the potassium absorption in chili plants is $76.71 \%$, and the remaining $23.29 \%$ is determined by other factors (Figure 5). There is a close positive correlation between dry canopy weight, seed weight, and $\mathrm{AMF}$ colonization to $\mathrm{N}$ and $\mathrm{P}$ uptake in soybean canopy tissue (Meghvansi et al. 2008). Also, in line with the study (Thioub et al. 2019), the effect of mycorrhizal inoculation was significantly positive $(\mathrm{P}$ $<0.001, \mathrm{R} 2=0.6389)$ with total $\mathrm{P}$ uptake of soybeans. 


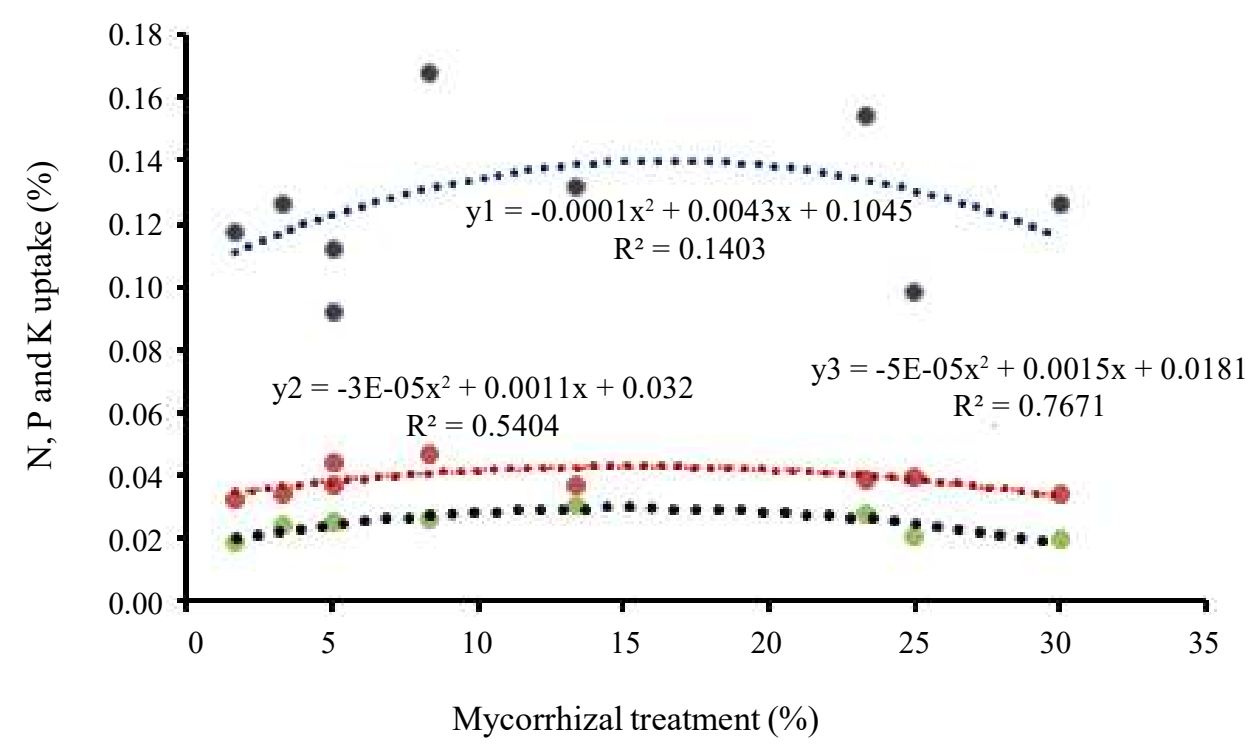

Figure 6 . Effect mychorrhizal infection on N, P, and K uptake of the cayenne plant. - Nitrigen uptake, Phosphorus uptake, = Potassium uptake.

\section{CONCLUSIONS}

Combining 20 g plant $^{-1}$ mycorrhiza and $50 \%$ rice husk biochar $+25 \%$ soil $+25 \%$ sand $\left(\mathrm{m}_{3} \mathrm{~b}_{1}\right)$ is the best dose for fresh canopy weight and mycorrhiza spore density. Based on $\mathrm{N}$ uptake, the best mycorrhizal treatment was found in $15 \mathrm{~g} \mathrm{plant}^{-1}$ with $50 \%$ wood biochar $+25 \%$ soil $+25 \%$ rice husk biochar. The correlation value, phosphorus uptake, potassium uptake, and fresh root weight have a positive and significant relationship with the percentage of mycorrhizal infections. Therefore, combined mycorrhizal treatment of 20 g plant $^{-1}$ and composition of $50 \%$ husk biochar + $25 \%$ soil $+25 \%$ sand, 15 g mycorrhizal dose treatment with $50 \%$ wood biochar $+25 \%$ soil + $25 \%$ rice husk biochar), and 20 g plant $^{-1}$ mycorrhiza are the best treatment as a plant growth medium. For further research, a combination of biochar and mycorrhiza requires the application to field plants to further observe the consistency of the yields results. The application of mycorrhizal inoculation, especially in chili plants, in further research is better applied at the seedling phase to make it more effective to use as inoculants.

\section{REFERENCES}

Adelman JM and JB Morton. 1986. Infectivity of vesicular-arbuscular mycorrhizal fungi influence of host-soil diluent combination on MPN estimates and percentage colonization. Soil Biol Biochem 18: 77-83. doi:10.1016/0038-0717(86)90106-9.
Aggarwal A, N Kadian, A Tanwar, A Yadav and KK Gupta. 2011. Role of arbuscular mycorrhizal fungi (AMF) in global sustainable development. $J$ Appl Nat Sci 3: 340-351.

Amendola C, A Montagnoli, M Terzaghi, D Trupiano, F Oliva, S Baronti, F Miglietta, D Chiatante and GS Scippa. 2017. Short-term effects of biochar on grapevine fine root dynamics and arbuscular mycorrhizae production. Agric Ecosyst Environ 239: 236-245. doi:10.1016/j.agee.2017.01.025.

An ZQ, JW Hendrix, DE Hershman and GT Henson. 1990. Evaluation of the "Most Probable Number" (MPN) and wet-sieving methods for determining soil-borne populations of endogeneous mycorrhizal fungi. Mycologia 82: 576-581. doi:10.2307/3760048.

Atkinson CJ, JD Fitzgerald and NA Hipps. 2010. Potential mechanisms for achieving agricultural benefits from biochar application to temperate soils: A review. Plant Soil 337: 1-18. doi:10.1007/s11104-010-0464-5.

Blackwell P, S Joseph, P Munroe, HM Anavar, P Storer, RJ Gilkes and ZM Solaiman. 2015. Influences of biochar and biochar-mineral complex on mycorrhizal colonization and nutrition of wheat and sorghum. Pedosphere 25: 686-695. doi:10.1016/ S1002-0160(15)30049-7.

Carballar-Hernández S, LV Hernández-Cuevas, NM Montaño, R Ferrera-Cerrato and A Alarcón. 2018. Species composition of native arbuscular mycorrhizal fungal consortia influences growth and nutrition of poblano pepper plants (Capsicum annuит L.). Appl Soil Ecol 130: 50-58. doi:10.1016/ j.apsoil.2018.05.022

Chan KY, L van Zwieten, I Meszaros, A Downie and S Joseph. 2007. Agronomic values of green waste biochar as a soil amendment. Aust J Soil Res 45: 629-634. doi:10.1071/SR07109. 
Chan KY, L van Zwieten, I Meszaros, A Downie and S Joseph. 2008. Using poultry litter biochars as soil amendments. Aust J Soil Res 46: 437-444. doi:10.1071/SR08036.

Chrysargyris A, M Prasad, A Kavanagh and N Tzortzakis. 2020. Biochar type, ratio, and nutrient levels in growing media affect seedling production and plant performance. Agronomy 10: 1-21. doi: 10.3390/agronomy10091421.

Dariah A, S Sutono, NL Nurida, W Hartatik and E Pratiwi. 2015. Pembenah tanah untuk meningkatkan produktivitas lahan pertanian [Soil enhancers to increase agricultural land productivity]. $J$ Sumberdaya Lahan 9: 67-84. doi:10.21082/ jsdl.v9n2.2015.\%25p.

Dorais M, C Martinez, M Diop, M Thériault, C Ménard and S Pepin. 2016. Assessing the potential of biochar as a growing media component for potted plants. Acta Hortic 1137: 19-26. doi: 10.17660/ ActaHortic.2016.1137.3.

Echave M, M Conti, A Clua, M Ruscitti and J Beltrano. 2005. Responses of mycorrhizal infection in the drought resistance and growth of Lotus glaber. Lotus Environ 35: 182-186.

Finlay RD. 2008. Ecological aspects of mycorrhizal symbiosis: With special emphasis on the functional diversity of interactions involving the extraradical mycelium. J Exp Bot 59: 1115-1126. doi:10.1093/ job/ern059.

Gaskin JW, Steiner C, Harris K, Das KC, Bibens B. 2008. Effect of low-temperature pyrolysis conditions on biochar for agriculture use. Am Soc Agric Biol Eng 51:2061-2069. doi:10.13031/2013.25409.

Glaser B, J Lehmann and W Zech. 2002. Ameliorating physical and chemical properties of highly weathered soils in the tropics with charcoal - A review. Biol Fertil Soils 35: 219-230. doi:10.1007/ s00374-002-0466-4.

Glaser B, K Wiedner, S Seelig, HP Schmidt and H Gerber. 2015. Biochar organic fertilizers from natural resources as a substitute for mineral fertilizers. Agron Sustain Dev 35: 667-678. doi:10.1007/s13593014-0251-4.

Hale SE, V Alling, V Martinsen, J Mulder, GD Breedveld and $\mathrm{G}$ Cornelissen. 2013. The sorption and desorption of phosphate-P, ammonium-N, and nitrate- $\mathrm{N}$ in cacao shell and corn cob biochars. Chemosphere 91: 1612-1619. doi:10.1016/ j.chemosphere.2012.12.057

Horel Á, E Tóth, G Gelybó, M Dencs $1 / 20$ and C Farkas. 2019. Biochar amendment affects soil water and $\mathrm{CO}_{2}$ regime during Capsicum annuum plant growth. Agronomy 9: 58. doi:10.3390/agronomy9020058.

Hu J, F Wu, S Wu, CL Lam, X Lin and MH Wong. 2014. Biochar and glomus caledonium influence cd accumulation of upland kangkong (Ipomoea Aquatica Forsk.) intercropped with Alfred stonecrop (Sedum alfredii Hance). Sci Rep 4: 1-7. doi:10.1038/srep04671.
Ioannidou O and A Zabaniotou. 2007. Agricultural residues as precursors for activated carbon production-A review. Renew Sustain Energy Rev 11: 1966-2005. doi:10.1016/j.rser.2006.03.013.

Jaya WS, AB Baharudin and M Mulyati. 2018. Pengaruh pemberian berbagai macam biochar dan dosis nitrogen terhadap pertumbuhan dan produksi kedelai (Glycine max L. Merill) [The effect of biochar kinds and dose of nitrogen on the growth and production of soybean (Gyline max L. Merill]. Crop Agro: J Ilmiah Budidaya Pertanian 11: 6070.

Karaca H, V Uygur, A Özkan and Z Kaya. 2013. Effects of mycorrhizae and fertilization on soybean yield and nutrient uptake. Commun Soil Sci Plant Anal 44: 37-41. doi:10.1080/00103624.2013.809730.

Karakas C, D Ozcimen and B Inan. 2017. Potential use of olive stone biochar as a hydroponic growing medium. J Analytic Appl Pyrolys 125: 17-23. doi: 10.1016/j.jaap.2017.05.005.

Karer J, B Wimmer, F Zehetner, S Kloss, S Feichtmair and B Kitzler. 2013. Biochar application to temperate soils - effects on soil fertility and crop yield under field conditions. Agric Food Sci 22: 390-403. doi:10.23986/ afsci.8155.

Kazemi F and R Mohorko. 2017. Review on the roles and effects of growing media on plant performance in green roofs in world climates. Urban Forest Urban Green 23: 13-26. doi:10.1016/j.ufug.2017.02.006.

Kormanik PP, WC Bryan and RC Schultz. 1980. Procedures and equipment for staining large numbers of plant root samples for endomycorrhizal assay. Canadian JMicrobiol 26: 536-538. doi:10.1139/m80-090.

Lehmann A, SD Veresoglou, EF Leifheit and MC Rillig. 2014. Arbuscular mycorrhizal influence on zinc nutrition in crop plants - A meta-analysis. Soil Biol Biochem 69: 123-131. doi:10.1016/ j.soilbio.2013.11.001.

Lehmann J, JP da Silva, C Steiner, T Nehls, W Zech and B Glaser. 2003. Nutrient availability and leaching in an archaeological Anthrosol and a Ferralsol of the Central Amazon basin: Fertilizer, manure and charcoal amendments. Plant Soil 249: 343-357. doi:10.1023/ A:1022833116184.

Lehmann J, MC Rillig, J Thies, CA Masiello, WC Hockaday and D Crowley. 2011. Biochar effects on soil biota - A review. Soil Biol Biochem 43: 18121836. doi:10.1016/j.soilbio.2011.04.022.

Li Y, J Cheng, X Lee, Y Chen, W Gao, W Pan and Y Tang. 2019. Effects of biochar-based fertilizers on nutrient leaching in tobacco-planting soil. Acta Geochim 38: 1-7. doi:10.1007/s11631-018-0307-2.

Liu L, J Li, F Yue, X Yan, F Wang, S Bloszies and Y Wang. 2018. Effects of arbuscular mycorrhizal inoculation and biochar amendment on maize growth, cadmium uptake, and soil cadmium speciation in $\mathrm{Cd}$ contaminated soil. Chemosphere 194: 495-503. doi:10.1016/j.chemosphere.2017.12.025. 
Meghvansi MK, K Prasad, D Harwan and SK Mahna. 2008. Response of soybean cultivars toward inoculation with three arbuscular mycorrhizal fungi and Bradyrhizobium japonicum in the alluvial soil. Eur J Soil Biol 44: 316-323. doi:10.1016/ j.ejsobi.2008.03.003.

Mickan BS, LK Abbott, K Stefanova and ZM Solaiman. 2016. Interactions between biochar and mycorrhizal fungi in a water-stressed agricultural soil. Mycorrhiza 26:565-574. doi:10.1007/s00572-016-0693-4.

Mulyani A and F Agus. 2017. Kebutuhan dan ketersediaan lahan cadangan untuk mewujudka citacita Indonesia sebagai lumbung pangan dunia tahun 2045 [The Need and Availability of Reserved Arable Land Realize Indonesian as the World Food Supplier in 2045]. Analisis Kebijakan Pertanian 15: 1-17. doi:10.21082/akp.v15n1.2017.1-17.

Nemati MR, F Simard, JP Fortin and J Eaudoin. 2015. Potential Use of Biochar in Growing Media. Vadose Zone J14:1-8. doi: 10.2136/vzj2014.06.0074.

Nguyen TTN, CY Xu, I Tahmasbian, R Che, Z Xu, X Zhou, HM Wallace and SH Bai. 2017. Effects of biochar on soil available inorganic nitrogen: A review and meta-analysis. Geoderma 288: 79-96. doi:10.1016/j.geoderma.2016.11.004.

Oguntunde PG, BJ Abiodun, AE Ajayi and N van de Giesen. 2008. Effects of charcoal production on soil physical properties in Ghana. J Plant Nutr Soil Sci 171:591-596. doi:10.1002/jpln.200625185.

Orta I. 2019. Role of microorganisms (Mycorrhizae) in organic farming. In Chandran S, Unni MR, Thomas S, editors. Organic Farm: Global Perspective and Methods. New Delhi, India: Elsevier.

Parnes R. 2013. Soil fertility a guide to organic and inorganic soil amendments. Available at: https:// soilandhealth.org/wp-content/uploads/01aglibrary/ 010189.fertle\%20soil\%20revise.pdf. [accessed 2019 March 3].

Rondon MA, J Lehmann, J Ramírez and M Hurtado. 2007. Biological nitrogen fixation by common beans (Phaseolus vulgaris L.) increases with bio-char additions. Biol Fertil Soil 43: 699-708. doi:10.1007/ s00374-006-0152-z.

Schnell RW, DM Vietor, TL Provin, CL Munster and S Capared. 2012. The capacity of biochar application to maintain energy crop productivity: Soil chemistry, sorghum growth, and runoff water quality effects. $J$ Environ Qual 41: 1044-1051. doi:10.2134/ jeq2011.0077.

Selvakumar G and P Thamizhiniyan. 2011. The effect of the arbuscular mycorrhizal ( AM ) Fungus glomus intraradices on the growth and yield of chili (Capsicum annuum L .) under salinity stress. World Appl Sci J 14: 1209-1214.
Selvakumar G, PH Yi, SE Lee, CC Shagol, SG Han, T Sa and BN Chung. 2018. Effects of long-term subcultured Arbuscular mycorrhizal fungi on red pepper plant growth and soil glomalin content. Mycobiology 46: 122-128. doi:10.1080/ 12298093.2018.1461315.

Sharma MP, SK Sharma, RD Prasad, KK Pal and R Dey. 2014. Application of arbuscular mycorrhizal fungi in production of annual oilseed crops. In: Solaiman Z, LK Abbott and V Ajit (eds). Mycorrhizal Fungi: Use in Sustainable Agriculture and Land Restoration, Soil Biology. Verlag Berlin Heidelberg: Springer; pp. 1-15.

Simanjuntak LHC, P Harsono and H Hasanudin. 2017. Kajian pertumbuhan dan hasil cabai rawit terhadap berbagai dosis pupuk hayati dan konsentrasi Indol Acetic Acid (IAA) [Study on the growth and yield of chili on various doses of biofertilizers and concentration of Indol Acetic Acid (IAA)]. Akta Agrosia 20: 9-16. doi:10.31186/aa.20.1.9-16.

Soil Research Center. 2009. Petunjuk Teknis Analisis Kimia Tanah, Tanaman, Air, dan Pupuk. $2^{\text {nd }}$ ed. Bogor: Soil Research Center. (in Indonesian).

Surdianto Y, N Sutrisna and S Basuno. 2015. Panduan Teknis Cara Membuat Arang Sekam Padi. West Java, Indonesia: Ministry of Agriculture. Available at: http://repository.pertanian.go.id/handle/ 123456789/6751. [accessed 2020 March 10].

Thioub M, N Ewusi-Mensah, J Sarkodie-Addo and T Adjei-Gyapong. 2019. Arbuscular mycorrhizal fungi inoculation enhances phosphorus use efficiency and soybean productivity on a Haplic Acrisol. Soil Till Res 192: 174-186. doi:10.1016/j.still.2019.05.001.

Van Zwieten L, S Kimber, S Morris, KY Chan, A Downie, J Rust, S Joseph and A Cowie. 2010. Effects of biochar from slow pyrolysis of papermill waste on agronomic performance and soil fertility. Plant Soil 327: 235-246. doi:10.1007/s11104-009-0050-X.

Wang W, J Shi, Q Xie, Y Jiang, N Yu and E Wang. 2017. Nutrient exchange and regulation in arbuscular mycorrhizal symbiosis. Mol Plant 10: 1147-1158. doi:10.1016/j.molp.2017.07.012.

Wubet T, I Kottke, D Teketay and F Oberwinkler. 2003. Mycorrhizal status of indigenous trees in dry Afromontane forests of Ethiopia. Forest Ecol Manage 179: 387-399. doi:10.1016/S03781127(02)00546-7.

Xiao TJ, QS Yang, W Ran, G Su and QR Shen. 2010. Effect of inoculation with arbuscular mycorrhizal fungus on nitrogen and phosphorus utilization in upland rice-mungbean intercropping system. Agric Sci China 9: 528-535. doi: 10.1016/S16712927(09)60126-7.

Zhang Z, A Mallik, J Zhang, Y Huang and L Zhou. 2019. Effects of arbuscular mycorrhizal fungi on inoculated seedling growth and rhizosphere soil aggregates. Soil Till Res 194: 104340. doi:10.1016/j.still.2019.104340. 